\title{
Structure and Diversity of Agroforestry Parks in the Tenghory District (Lower Casamance, Senegal)
}

\author{
Ismaila Coly ${ }^{1, ~ *, ~ A l i o u ~ B a d j i ~}{ }^{1}$, Daouda Ngom $^{2}$, Arfang Ousmane Kemo Goudiaby ${ }^{1}$, Mamady Drame ${ }^{1}$ \\ ${ }^{1}$ Department of Agroforestry, Agroforestry and Ecology Laboratory, Assane SECK University, Ziguinchor, Senegal \\ ${ }^{2}$ Department of Plant Biology, Plant Ecology Laboratory, Cheikh Anta DIOP University, Dakar, Senegal
}

Email address:

icoly@univ-zig.sn(I. Coly)

${ }^{*}$ Corresponding author

To cite this article:

Ismaila Coly, Aliou Badji, Daouda Ngom, Arfang Ousmane Kemo Goudiaby, Mamady Drame. Structure and Diversity of Agroforestry Parks in the Tenghory District (Lower Casamance, Senegal). American Journal of Agriculture and Forestry. Vol. 8, No. 5, 2020 , pp. $198-207$. doi: 10.11648/j.ajaf.20200805.13

Received: August 24, 2020; Accepted: September 17, 2020; Published: September 24, 2020

\begin{abstract}
In Lower Casamance, farmers deliberately keep certain woody species in their fields to increase their crop yields and generate additional income. The objective of this study is to contribute to a better understanding of the state of agroforestry parks in Lower Casamance. To achieve this objective, vegetation surveys were carried out. Thus, a square plot of $2500 \mathrm{~m}^{2}$ $(50 \mathrm{~m} \times 50 \mathrm{~m})$ was installed in the fields of each of the 99 farmers selected in the sample, for a total of 99 plots. This sample is distributed among the different municipalities of the arrondissement in proportion to their demographic weight, ie $18 ; 14 ; 14$; 53 plots respectively in the municipalities of Coubalan, Ouonck, Niamone and Tenghory. The agroforestry parks in the district of Tenghory have a specific richness of 64 woody species divided into 53 genera and 20 botanical families. The observed density of trees is 21.8 feet / ha, the basal area is $3.3 \mathrm{~m}^{2} /$ ha with a coverage rate of $13.7 \%$. The height class structure of the woody stand reveals a predominance of individuals $\geq 10 \mathrm{~m}$ in height $(50.5 \%)$. The diameter class [5-25] is the best represented with $45.8 \%$ of the individuals. These results thus constitute a source of useful information for the rational management of agroforestry parks in the district of Tenghory.
\end{abstract}

Keywords: Characterization, Flora, Woody Vegetation, Agroforestry Parks, Tenghory

\section{Introduction}

In West Africa, agriculture is marked by a traditional landuse system, where trees dot the cultivated or recently ploughed fields called "agroforestry parks" [1]. In these fields, farmers keep the trees that are not very troublesome or useful and sometimes introduce new species that are part of the cropping system [2]. These parks are exploited by the populations, who earn additional income from tree products. The importance of this traditional land-use system for the populations has been confirmed by several studies in West Africa [3-7]. In spite of the proven importance of agroforestry parks in the life of the populations, a degradation of these systems is observed nowadays. Thus, in the Sudanian zone, anthropic action combined with climatic deterioration has led to a regression of woody vegetation in agroforestry parks [8, 9]. In Senegal, a continuous degradation of agroforestry parks has been observed [10]. This threatens their sustainability given the increased pressure on them [3]. Therefore, it is of paramount importance to know the current state of agroforestry parks in order to have a basis for proposing a rational and sustainable management of these important ecosystems. However, in Lower Casamance, there are very few studies on the state of agroforestry parks [11]. It is in this context that this work is carried out with the aim of establishing the floristic and structural characteristics of the woody vegetation of the agroforestry parks in the Tenghory district.

\section{Materials and Methods}

\subsection{The Study Area}

The Tenghory district is located in the department of Bignona, region of Ziguinchor. It is made up of four rural 
municipalities (Tenghory, Niamone, Coubalan and Ouonck) in which the study is carried out. It is located in the southeast of the Bignona department and is bordered to the north by the district of Sindian, to the south by the department of Ziguinchor, to the west by the district of Tendouck, and to the east by the region of Sédhiou (Figure 1).
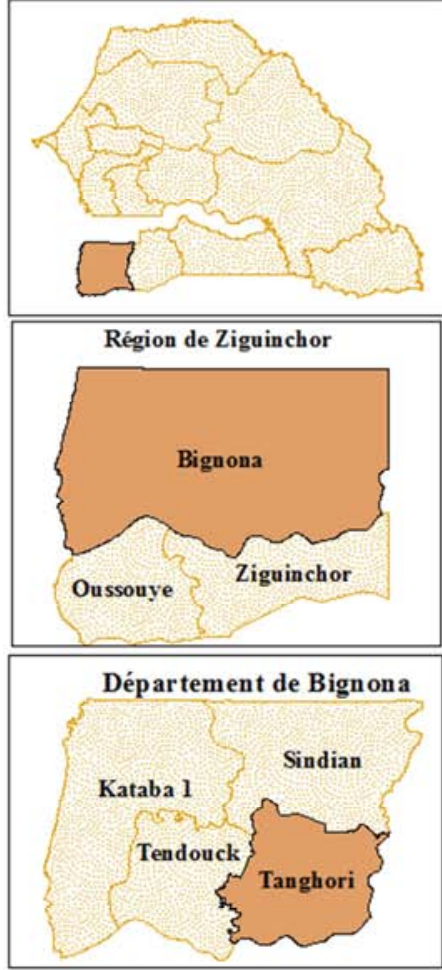

- Communes rurales

Chef-lieu d'Arrondissem ent

Commune

- Réseau routier

Cours d'eau simple

$2=$ Surfaces boisées

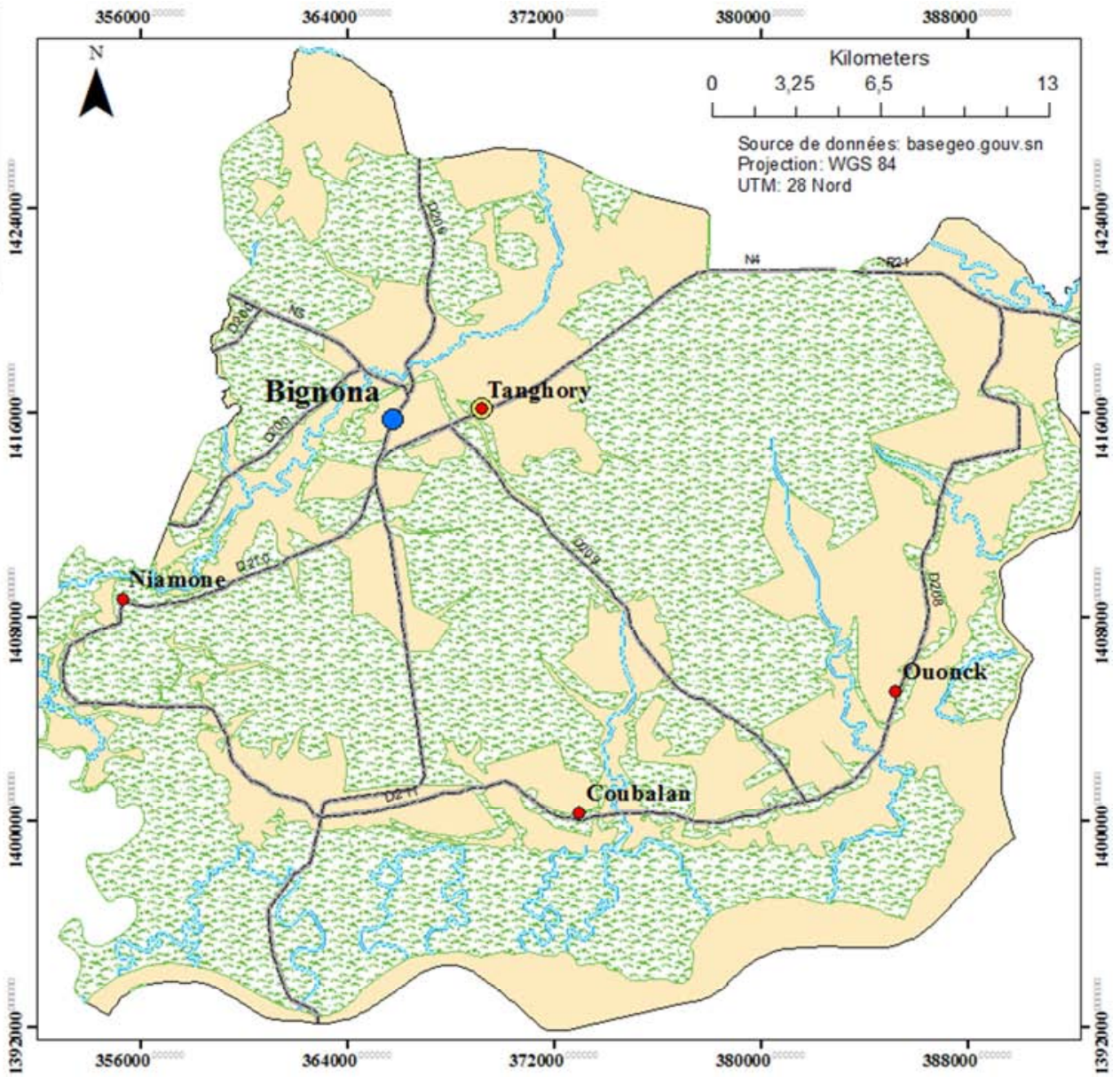

Figure 1. Location map of the district of Tenghory.
The study area in Lower Casamance has a southern Sudanese coastal climate with two seasons: a dry season and a rainy season [12]. The average annual rainfall over the 1980-2018 series is $1302.04 \mathrm{~mm}$. The wettest year of the observed series (1999), recorded 1946.1mm of rain, while the two most deficit years are $1980(745.6 \mathrm{~mm})$ and 2002 $(811.7 \mathrm{~mm})$ (Figure 2). The mean values of the monthly minimum and maximum temperatures recorded at the Ziguinchor weather station are $21.5^{\circ} \mathrm{C}$ and $35^{\circ} \mathrm{C}$ respectively in the period from 1990 to 2016 .

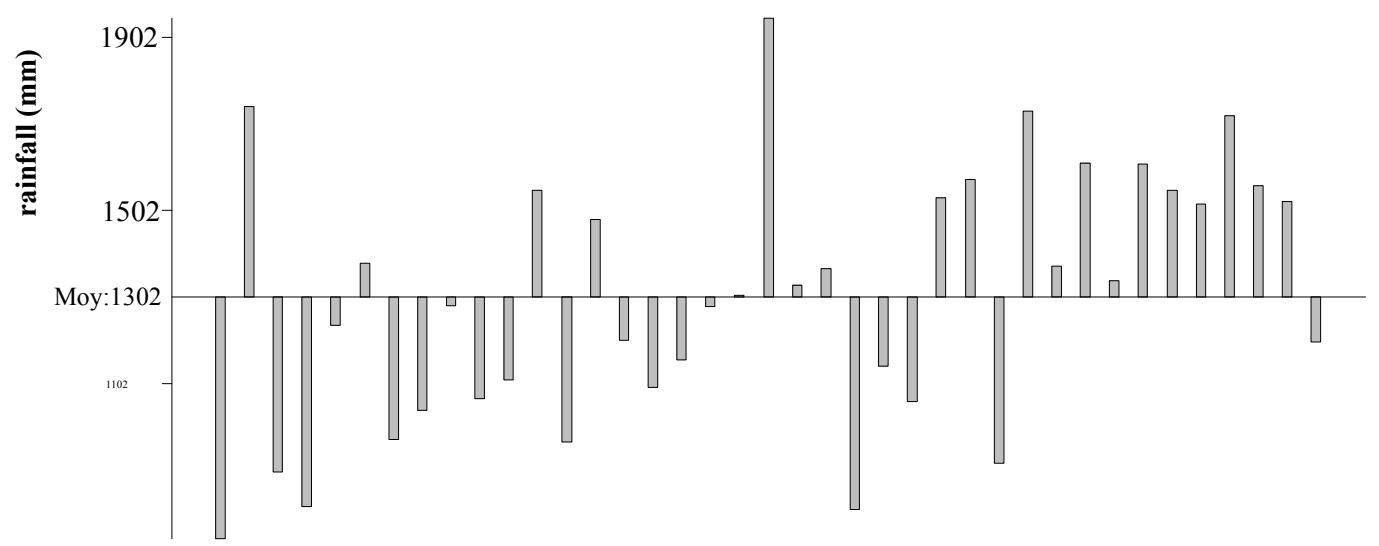

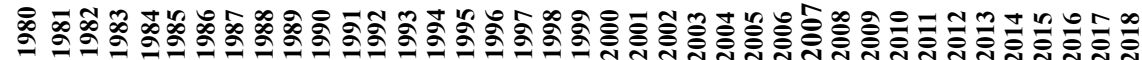

Figure 2. Interannual variation in rainfall from 1980 to 2018 in the Lower Casamance region. 
There are two types of soils on the continental shelf: leached tropical ferruginous soils and low to medium desaturated ferralitic soils.

Floodplains are of various forms: raw mineral soils of nonclimatic origin with marine and fluviomarine inputs, poorly evolved soils of non-climatic origin with modal inputs, peat hydromorphic organic soils, humic hydromorphic medium organic soils and halomorphic soils with non-degraded structure, saline, acidified $[13,14]$.

\subsection{Woody Vegetation Survey}

A stratified sampling was carried out at the agroforestry parks in the Tenghory borough to study the woody vegetation by considering the 4 rural municipalities of the district as strata. For this purpose, a sample of 17 villages out of the 82 villages in the district was selected. These villages are distributed among the four rural communes of the district. Then, 99 square plots of $2500 \mathrm{~m}^{2}$ (50 m side) were installed at the rate of one plot in the fields of each selected farmer. The plots were distributed among the communes and then among the selected villages in proportion to their demographic weight. The choice of villages in the commune was made on the basis of their geographical distribution in order to ensure a good network of each municipality. The criterion that guided the choice of farm managers was the ownership of a cultivated field. Thus, throughout the district, 18 plots have been set up in the municipality of Coubalan, 14 in the municipality of Niamone, 14 in the municipality of Ouonck and 53 in the municipality of Tenghory.

The geographical coordinates of each plot were recorded using GPS and an exhaustive census of species was carried out. For each individual, height was measured using a suunto dendrometer, tree trunk diameter at chest height using a forest compass, cross-diameter of the crown (East-West and North-South direction) using a metric tape, and counts of young trees were made to assess regeneration. Woody trees with a diameter of less than $5 \mathrm{~cm}$ at $1.30 \mathrm{~m}$ were considered regeneration [15].

To delineate the plots, a metric tape, rope and stakes were used. Method 3-4-5 based on the Pythagorean theorem was used to determine the four right angles of the plot.

\subsection{Data Processing}

Data entry and the preparation of tables and graphs were carried out with the Excel spreadsheet. The Principal Component Analysis (PCA) was carried out using the software $\mathrm{R}$ version 3.5.3. Several formulas were used to calculate the vegetation parameters.

Specific frequency: This provides information on the distribution of a species in a stand. It can be expressed as an absolute value or as a percentage (\%). It is calculated by the following formula [16]: $\mathrm{F}=\mathrm{Nri} / \mathrm{Nr}$

$\mathrm{F}=$ frequency of occurrence expressed as a percentage $(\%) ; \mathrm{Nri}=$ number of records where species $\mathrm{i}$ is present and
$\mathrm{Nr}=$ total number of records

Species richness: This has been assessed on the basis of total species richness, which is the total number of species in the stand in a given ecosystem [17].

Density (true density): is the number of individuals per unit area (ha). It is the ratio of the total number of individuals in the sample $(\mathrm{N})$ by the sampled area (s) $\mathrm{D}=\mathrm{N} / \mathrm{S}$

The basal area, which is the area occupied by the tree at the base of its trunk. It is expressed in square metres per hectare $\left(\mathrm{m}^{2}\right.$. ha. $\left.^{-1}\right)$,

$$
\mathrm{St}=\frac{\sum \pi\left(\frac{\mathrm{d} 1,30}{2}\right)^{2}}{\mathrm{SE}}
$$

Where $\mathrm{St}=$ basal area; $\mathrm{d} 1.30=$ trunk diameter in $\mathrm{m}$ at 1.30 $\mathrm{m}$ from the ground; $\mathrm{SE}=$ area of the sample under consideration in ha.

The woody canopy which is the area covered by the vertical projection of the tree crown on the ground. It is calculated in square metres per ha.

$$
\mathrm{C}=\frac{\sum \pi\left(\frac{\mathrm{dmh}}{2}\right)^{2}}{S E}
$$

Where $\mathrm{C}=$ woody cover; $\mathrm{dmh}=$ mean crown diameter in $\mathrm{m} ; \mathrm{S}=$ area of the sample under consideration in ha

Shannon Weaver's index $\left(\mathrm{H}^{\prime}\right)$, which considers both abundance and species richness, is used to assess the distribution of individuals according to species. It ranges from 0 to 4.5. The index is minimum when all individuals belong to the same species. It is maximum when each individual represents a distinct species [18]. It can be expressed in bits and its formula is:

$$
\mathrm{H}^{\prime}=-\sum \text { pi } \log 2 \mathrm{pi}
$$

$\mathrm{Pi}=$ relative abundance of each species.

The evenness index (E) provides information on the distribution of species abundance in the stand. The regularity index appears to be a more rigorous comparison term [19]. It is between 0 and 1 and tends towards 0 when all the individuals correspond to a single species. It tends towards 1 when each species is represented by the same number of individuals [20]. This index is given by the following formula:

$$
\mathrm{E}=\mathrm{H}^{\prime} / \mathrm{Hmax}
$$

$\operatorname{Hmax}=\log 2(\mathrm{~S}) \mathrm{S}=$ total number of species.

\section{Results}

\subsection{Floristic Composition}

The study of the agroforestry parks in the Tenghory district identified sixty-four (64) woody species divided into fifty-three (53) genera and 20 botanical families. Of the 64 species inventoried, the municipality of Tenghory recorded more species (57 species) divided into 49 genera and 19 families. 
Table 1. Floristic composition of the agroforestry parks according to the municipalities of the Tenghory district.

\begin{tabular}{|c|c|c|c|c|c|c|}
\hline \multirow{2}{*}{ Families } & \multirow{2}{*}{ Genera } & \multirow{2}{*}{ Species } & \multicolumn{4}{|c|}{ Municipalities } \\
\hline & & & Teng. & Ouo. & Coub. & Niam. \\
\hline \multirow{3}{*}{ Anacardiaceae } & Anacardium & Anacardium occidentale L. & + & + & + & + \\
\hline & Mangifera & Mangifera indica L. & + & + & + & + \\
\hline & Spondias & Spondias monbin L. & + & - & + & - \\
\hline \multirow{2}{*}{ Annonaceae } & Annona & Annona senegalensis Pers. & + & - & - & - \\
\hline & Uvaria & Uvaria chamae P. Beauv. & + & - & - & - \\
\hline \multirow{4}{*}{ Apocynaceae } & Calotropis & Calotropis procera (Ait.) Ait. f. & + & - & - & - \\
\hline & Holarrhena & Holarrhena floribunda (G. Don) Dur. \& Schinz & + & - & + & + \\
\hline & Landolphia & Landolphia heudelotii A. DC. & + & - & + & - \\
\hline & Saba & Saba senegalensis (A. DC.) Pichon & - & - & + & - \\
\hline \multirow{2}{*}{ Arecaceae } & Borassus & Borassus akeassii Bayton, Ouédraogo \& Guinko & + & - & - & + \\
\hline & Elaeis & Elaeis guineensis Jacq. & + & + & - & + \\
\hline \multirow{2}{*}{ Bignoniaceae } & Markhamia & Markhamia tomentosa (Benth.) K. Schum. ex Engl. & + & - & + & + \\
\hline & Newbouldia & Newbouldia laevis (P. Beauv.) Seem. & + & + & + & + \\
\hline Chrysobalanaceae & Neocarya & Neocarya macrophylla (Sabine) Prance & + & - & - & + \\
\hline \multirow{8}{*}{ Combretaceae } & \multirow{5}{*}{ Combretum } & Combretum glutinosum Perr. ex DC. & + & - & - & - \\
\hline & & Combretum lecardii Engl. \& Diels & + & + & - & + \\
\hline & & Combretum micranthum G. Don & + & - & + & + \\
\hline & & Combretum nigricans Lepr. ex Guill. et Perr. & + & - & + & - \\
\hline & & Combretum paniculatum Vent. & + & - & - & - \\
\hline & Guiera & Guiera senegalensis J. F. Gmel. & + & + & + & + \\
\hline & \multirow{2}{*}{ Terminalia } & Terminalia macroptera Guill. \& Perr. & + & + & + & + \\
\hline & & Terminalia mollis Laws. & - & - & + & - \\
\hline \multirow{19}{*}{ Fabaceae } & Acacia & Acacia holosericea A. Cunn. ex G. Don & - & - & + & - \\
\hline & Afzelia & Afzelia africana Smith ex Pers. & + & - & - & - \\
\hline & Albizia & Albizia adianthifolia (Schumach.) W. F. Wight & + & - & + & - \\
\hline & Cassia & Cassia sieberiana DC. & + & + & + & + \\
\hline & Cordyla & Cordyla pinnata (Lepr. ex A. Rich.) Milne-Redhead & + & - & + & - \\
\hline & Daniellia & Daniellia oliveri (Rolfe) Hutch. \& Dalz. & + & - & + & - \\
\hline & \multirow{2}{*}{ Detarium } & Detarium microcarpum Guill. \& Perr. & - & - & + & - \\
\hline & & Detarium senegalense Gmel. & + & - & - & + \\
\hline & Dialium & Dialium guineense Willd. & + & - & - & - \\
\hline & Dichrostachys & Dichrostachys cinerea (L.) Wight \& Arn. & + & + & + & + \\
\hline & Erythrina & Erythrina senegalensis DC. & + & + & - & + \\
\hline & Erythrophleum & Erythrophleum africanum Afzel. & + & - & + & - \\
\hline & Faidherbia & Faidherbia albida (Del.) Chev. & + & + & + & + \\
\hline & Parkia & Parkia biglobosa (Jacq.) R. Br. ex G. Don & + & + & + & + \\
\hline & Piliostigma & Piliostigma reticulatum (DC.) Hochst. & + & - & - & - \\
\hline & Finustigma & Piliostigma thonningii (Schumach.) Milne-Redh. & + & + & - & + \\
\hline & Prosopis & Prosopis africana (Guill. \& Perr.) Taub. & + & + & + & + \\
\hline & Pterocarpus & Pterocarpus erinaceus Poir. & + & - & + & - \\
\hline & Senna & Senna alata (L.) Roxb. & + & - & - & - \\
\hline \multirow[t]{2}{*}{ Icacinaceae } & Icacina & Icacina senegalensis Juss. & + & + & + & + \\
\hline & Adansonia & Adansonia digitata $\mathrm{L}$. & + & + & - & + \\
\hline \multirow[t]{3}{*}{ Malvaceae } & Bombax & Bombax costatum Pellegr. \& Vuillet & + & - & + & + \\
\hline & Cola & Cola cordifolia (Cav.) R. Br. & + & - & - & - \\
\hline & Azadirachta & Azadirachta indica A. Juss. & + & + & - & + \\
\hline \multirow[t]{4}{*}{ Meliaceae } & Ekebergia & Ekebergia senegalensis A. Juss. & - & + & - & - \\
\hline & Khaya & Khaya senegalensis (Desr.) A. Juss. & + & - & + & + \\
\hline & Antiaris & Antiaris africana Engl & + & - & + & - \\
\hline & & Ficus dicranostyla Mildbr. & + & + & - & - \\
\hline Moraceae & Ficus & Ficus exasperata Vahl & + & - & - & - \\
\hline & Ficus & Ficus glumosa Del. & + & - & - & + \\
\hline & & Ficus sycomorus ssp. gnaphalocarpa (Miq.) C. C. Berg & - & - & + & + \\
\hline Myrtaceae & Eucalyptus & Eucalyptus camaldulensis Dehnh. & - & - & - & + \\
\hline Polygalaceae & Securidaca & Securidaca longipedunculata Fres. & + & - & - & + \\
\hline Rhamnaceae & Ziziphus & Ziziphus mauritiana Lam. & + & + & - & - \\
\hline
\end{tabular}




\begin{tabular}{|c|c|c|c|c|c|c|}
\hline \multirow{2}{*}{ Families } & \multirow{2}{*}{ Genera } & \multirow{2}{*}{ Species } & \multicolumn{4}{|c|}{ Municipalities } \\
\hline & & & Teng. & Ouo. & Coub. & Niam. \\
\hline \multirow{2}{*}{ Rubiaceae } & Gardenia & Gardenia ternifolia Schumach. \& Thonn. & + & + & - & + \\
\hline & Sarcocephalus & Sarcocephalus latifolius (Smith) Bruce & + & - & - & - \\
\hline \multirow{2}{*}{ Rutaceae } & \multirow{2}{*}{ Citrus } & Citrus limon (L.) Burm. f. & + & - & - & + \\
\hline & & Citrus sinensis (L.) Osbeck & + & - & - & - \\
\hline Simaroubaceae & Hannoa & Hannoa undulata (Guill. \& Perr.) Planch. & + & - & + & - \\
\hline Ulmaceae & Celtis & Celtis integrifolia Lam. & + & - & + & - \\
\hline \multirow{2}{*}{ Verbenaceae } & Vitex & Vitex doniana Sweet & + & + & + & + \\
\hline & Gmelina & Gmelina arborea Roxb. & + & - & - & - \\
\hline Total 20 & 53 & 64 & 57 & 22 & 33 & 32 \\
\hline
\end{tabular}

+: Presence; -: Absence

Legend: Ouo: Ouonck; Teng: Tenghory; Coub: Coubalan; Niam: Niamone

In the municipality of Coubalan, 33 species divided into 31 genera and 12 families were recorded. Niamone municipality recorded 32 species in 30 genera and 16 families. The municipality of Ouonck recorded the fewest species $(22$ species) divided into 22 genera and 12 families (Table 1). The families that predominate at the district level are the Fabaceae (29.7\%), the Combretaceae (12.5\%) and the Moraceae $(7.8 \%)$. The same trend is observed in the municipality of Tenghory with the predominant botanical families being Fabaceae (29.8\%), Combretaceae (12.3\%) and Moraceae $(7.0 \%)$. In the municipality of Coubalan, Fabaceae (36.4\%), Combretaceae (15.2\%) and Anacardiaceae $(9.1 \%)$ are the predominant botanical families. These are the same families that predominate in the municipality of Ouonck with $31.8 \%$ of the species for the Fabaceae, $13.6 \%$ of the species for the Combretaceae and $9.1 \%$ of the species for the Anacardiaceae. As for the municipality of Niamone, the families that predominate there are: the Fabaceae (25\%), the Combretaceae (12.5\%) and the Anacardiaceae with $6.3 \%$ of the species (Table 2).

Table 2. Relative importance of families (\%) by municipality and Tenghory dictrict.

\begin{tabular}{|c|c|c|c|c|c|}
\hline \multirow{2}{*}{ Families } & \multicolumn{4}{|c|}{ Municipalities } & \multirow{2}{*}{ Tenghory district } \\
\hline & Tenghory & Ouonck & Coubalan & Niamone & \\
\hline Fabaceae & 29,8 & 31,8 & 36,4 & 25,0 & 29,7 \\
\hline Combretaceae & 12,3 & 13,6 & 15,2 & 12,5 & 12,5 \\
\hline Moraceae & 7,0 & 4,5 & 6,1 & 6,25 & 7,8 \\
\hline Apocynaceae & 5,3 & 0,0 & 9,09 & 3,1 & 6,3 \\
\hline Anacardiaceae & 5,3 & 9,1 & 9,1 & 6,3 & 4,7 \\
\hline Malvaceae & 5,3 & 4,5 & 3,0 & 6,25 & 4,7 \\
\hline Meliaceae & 3,5 & 9,09 & 3,0 & 6,25 & 4,7 \\
\hline Annonaceae & 3,5 & 0,0 & 0,0 & 0,0 & 3,1 \\
\hline Arecaceae & 3,5 & 4,5 & 0,0 & 6,3 & 3,1 \\
\hline Bignoniaceae & 3,5 & 4,5 & 6,1 & 6,3 & 3,1 \\
\hline Rubiaceae & 3,5 & 4,5 & 0,0 & 3,1 & 3,1 \\
\hline Rutaceae & 3,5 & 0,0 & 0,0 & 3,1 & 3,1 \\
\hline Verbenaceae & 3,5 & 4,5 & 3,0 & 3,1 & 3,1 \\
\hline Chrysobalanaceae & 1,8 & 0,0 & 0,0 & 3,1 & 1,6 \\
\hline Icacinaceae & 1,8 & 4,5 & 3,0 & 3,1 & 1,6 \\
\hline Myrtaceae & 0,0 & 0,0 & 0,0 & 3,1 & 1,6 \\
\hline Polygalaceae & 1,8 & 0,0 & 0,0 & 3,1 & 1,6 \\
\hline Rhamnaceae & 1,8 & 4,5 & 0,0 & 0,0 & 1,6 \\
\hline Simaroubaceae & 1,8 & 0,0 & 3,0 & 0,0 & 1,6 \\
\hline Ulmaceae & 1,8 & 0,0 & 3,0 & 0,0 & 1,6 \\
\hline
\end{tabular}

\subsection{Frequency Analysis}

The woody vegetation of the agroforestry parks in the Tenghory district is rich in 64 species. Of these, Icacina senegalensis Juss. is the most common (74.7\%). It is followed by Guiera senegalensis J. F. Gmel. (64.6\%), Terminalia macroptera Guill. \& Perr. (48.5\%) and Cassia sieberiana DC. (45.5\%).

In the municipality of Tenghory, the most frequent species in agroforestry parks are Icacina senegalensis (77.4\%), Guiera senegalensis J. F. Gmel. (60.4\%) and Terminalia macroptera Guill. \& Perr. (50.9\%).

In the commune of Ouonck, Icacina senegalensis is the most frequent species $(100 \%)$. It is followed by Guiera senegalensis J. F. Gmel. (78.6\%) and Faidherbia albida (64.3\%).

The most frequent species in the parks of the municipality of Coubalan are: Terminalia macroptera Guill. \& Perr. (61.1\%), Pterocarpus erinaceus Poir. (61.1\%) and Guiera 
senegalensis J. F. Gmel. (55.6\%).

And in the municipality of Niamone, the species with a high frequency of occurrence in the parks are Guiera senegalensis J. F. Gmel. (78.6\%), Icacina senegalensis Juss. (78.6\%) and Cassia sieberiana DC. (71.4\%) (Table 3).

Table 3. Specific frequencies (\%) of woody trees in the different municipalities of the Tenghory district.

\begin{tabular}{|c|c|c|c|c|c|}
\hline Species & Teng. district & Muni. Teng & Muni. Ouo & Muni. Coub & Muni. Niam \\
\hline Icacina senegalensis Juss. & 74,7 & 77,4 & 100,0 & 44,4 & 78,6 \\
\hline Guiera senegalensis J. F. Gmel. & 64,6 & 60,4 & 78,6 & 55,6 & 78,6 \\
\hline Terminalia macroptera Guill. \& Perr. & 48,5 & 50,9 & 21,4 & 61,1 & 50,0 \\
\hline Cassia sieberiana DC. & 45,5 & 47,2 & 28,6 & 33,3 & 71,4 \\
\hline Dichrostachys cinerea (L.) Wight \& Arn. & 37,4 & 39,6 & 14,3 & 55,6 & 28,6 \\
\hline Parkia biglobosa (Jacq.) R. Br. ex G. Don & 35,4 & 45,3 & 28,6 & 22,2 & 21,4 \\
\hline Anacardium occidentale L. & 33,3 & 39,6 & 28,6 & 16,7 & 35,7 \\
\hline Azadirachta indica A. Juss. & 27,3 & 32,1 & 28,6 & 0,0 & 42,9 \\
\hline Combretum micranthum G. Don & 27,3 & 28,3 & 0,0 & 50,0 & 21,4 \\
\hline Newbouldia laevis (P. Beauv.) Seem. & 27,3 & 35,8 & 7,1 & 16,7 & 28,6 \\
\hline Elaeis guineensis Jacq. & 26,3 & 37,7 & 7,1 & 0,0 & 35,7 \\
\hline Vitex doniana Sweet & 26,3 & 24,5 & 7,1 & 44,4 & 28,6 \\
\hline Pterocarpus erinaceus Poir. & 25,3 & 26,4 & 0,0 & 61,1 & 0,0 \\
\hline Prosopis africana (Guill. \& Perr.) Taub. & 24,2 & 30,2 & 21,4 & 11,1 & 21,4 \\
\hline Faidherbia albida (Del.) Chev. & 21,2 & 15,1 & 64,3 & 16,7 & 7,1 \\
\hline Holarrhena floribunda (G. Don) Dur. \& Schinz & 21,2 & 22,6 & 0,0 & 44,4 & 7,1 \\
\hline Piliostigma thonningii (Schumach.) Milne-Redh. & 20,2 & 34,0 & 7,1 & 0,0 & 7,1 \\
\hline Borassus akeassii Bayton, Ouédraogo \& Guinko & 18,2 & 28,3 & 0,0 & 0,0 & 21,4 \\
\hline Annona senegalensis Pers & 15,2 & 28,3 & 0,0 & 0,0 & 0,0 \\
\hline Daniellia oliveri (Rolfe) Hutch. \& Dalz. & 15,2 & 26,4 & 0,0 & 5,6 & 0,0 \\
\hline Hannoa undulata (Guill. \& Perr.) Planch. & 13,1 & 11,3 & 0,0 & 38,9 & 0,0 \\
\hline Mangifera indica $\mathrm{L}$. & 12,1 & 13,2 & 7,1 & 16,7 & 7,1 \\
\hline Khaya senegalensis (Desr.) A. Juss. & 11,1 & 17,0 & 0,0 & 5,6 & 7,1 \\
\hline Combretum nigricans Lepr. ex Guill. et Perr. & 10,1 & 1,9 & 0,0 & 50,0 & 0,0 \\
\hline Securidaca longipedunculata Fres. & 10,1 & 17,0 & 0,0 & 0,0 & 7,1 \\
\hline Citrus limon (L.) Burm. f. & 8,1 & 13,2 & 0,0 & 0,0 & 7,1 \\
\hline Gardenia ternifolia Schumach. \& Thonn. & 8,1 & 7,5 & 7,1 & 0,0 & 21,4 \\
\hline Bombax costatum Pellegr. \& Vuillet & 7,1 & 1,9 & 0,0 & 27,8 & 7,1 \\
\hline Erythrina senegalensis DC. & 7,1 & 9,4 & 7,1 & 0,0 & 7,1 \\
\hline Ficus glumosa Del. & 7,1 & 9,4 & 7,1 & 0,0 & 7,1 \\
\hline Cola cordifolia (Cav.) R. Br. & 5,1 & 9,4 & 0,0 & 0,0 & 0,0 \\
\hline Landolphia heudelotii A. DC. & 5,1 & 1,9 & 0,0 & 22,2 & 0,0 \\
\hline Celtis integrifolia Lam. & 4,0 & 5,7 & 0,0 & 5,6 & 0,0 \\
\hline Cordyla pinnata (Lepr. ex A. Rich.) Milne-Redhead & 4,0 & 3,8 & 0,0 & 11,1 & 0,0 \\
\hline Erythrophleum africanum Afzel. & 4,0 & 5,7 & 0,0 & 5,6 & 0,0 \\
\hline Neocarya macrophylla (Sabine) Prance & 4,0 & 5,7 & 0,0 & 0,0 & 7,1 \\
\hline Detarium senegalense Gmel. & 3,0 & 3,8 & 0,0 & 0,0 & 7,1 \\
\hline Ziziphus mauritiana Lam. & 3,0 & 1,9 & 14,3 & 0,0 & 0,0 \\
\hline Afzelia africana Smith ex Pers. & 2,0 & 3,8 & 0,0 & 0,0 & 0,0 \\
\hline Albizia adianthifolia (Schumach.) W. F. Wight & 2,0 & 1,9 & 0,0 & 5,6 & 0,0 \\
\hline Antiaris africana Engl. & 2,0 & 1,9 & 0,0 & 5,6 & 0,0 \\
\hline Calotropis procera (Ait.) Ait. f. & 2,0 & 3,8 & 0,0 & 0,0 & 0,0 \\
\hline Citrus sinensis (L.) Osbeck & 2,0 & 3,8 & 0,0 & 0,0 & 0,0 \\
\hline Combretum paniculatum Vent. & 2,0 & 3,8 & 0,0 & 0,0 & 0,0 \\
\hline Dialium guineense Willd. & 2,0 & 3,8 & 0,0 & 0,0 & 0,0 \\
\hline Eucalyptus camaldulensis Dehnh. & 2,0 & 0,0 & 0,0 & 0,0 & 7,1 \\
\hline Ficus dicranostyla Mildbr. & 2,0 & 1,9 & 0,0 & 0,0 & 0,0 \\
\hline Ficus exasperata Vahl & 2,0 & 1,9 & 0,0 & 0,0 & 0,0 \\
\hline Ficus sycomorus (Miq.) C. C. Berg & 2,0 & 0,0 & 0,0 & 5,6 & 7,1 \\
\hline Gmelina arborea Roxb. & 2,0 & 1,9 & 0,0 & 0,0 & 0,0 \\
\hline Sarcocephalus latifolius (Smith) Bruce & 2,0 & 1,9 & 0,0 & 0,0 & 0,0 \\
\hline Senna alata (L.) Roxb. & 2,0 & 1,9 & 0,0 & 0,0 & 0,0 \\
\hline Uvaria chamae P. Beauv. & 2,0 & 3,8 & 0,0 & 0,0 & 0,0 \\
\hline Acacia holosericea A. Cunn. ex G. Don & 1,0 & 0,0 & 0,0 & 5,6 & 0,0 \\
\hline Combretum glutinosum Perr. ex DC. & 1,0 & 1,9 & 0,0 & 0,0 & 0,0 \\
\hline Detarium microcarpum Guill. \& Perr. & 1,0 & 0,0 & 0,0 & 5,6 & 0,0 \\
\hline Ekebergia senegalensis A. Juss. & 1,0 & 0,0 & 7,1 & 0,0 & 0,0 \\
\hline
\end{tabular}




\begin{tabular}{|c|c|c|c|c|c|}
\hline Species & Teng. district & Muni. Teng & Muni. Ouo & Muni. Coub & Muni. Niam \\
\hline Piliostigma reticulatum (DC.) Hochst. & 1,0 & 1,9 & 0,0 & 0,0 & 0,0 \\
\hline Saba senegalensis (A. DC.) Pichon & 1,0 & 0,0 & 0,0 & 5,6 & 0,0 \\
\hline Terminalia mollis Laws. & 1,0 & 0,0 & 0,0 & 5,6 & 0,0 \\
\hline
\end{tabular}

Legend: Teng. district: Tenghory district; Muni. Ouo: Municipality of Ouonck; Muni. Teng: Municipality of Tenghory; Muni. Coub: Municipality of Coubalan; Muni. Niam: Municipality of Niamone

\subsection{Structural Characteristics of Woody Vegetation in Parks}

The average coverage rate for all agroforestry parks in the Tenghory district is $13.7 \%$. It is higher in the municipality of Tenghory $(15.9 \%)$ followed by that of Ouonck $(15.3 \%)$. The municipalies of Coubalan and Niamone have coverage rates of 11.7 per cent and 6.4 per cent respectively (Table 4). The species with the highest recovery rates at the district level are Faidherbia albida (2.5\%), Parkia biglobosa (1.8\%) and Pterocarpus erinaceus $(0.9 \%)$.

The basal area of all the agroforestry parks in the district is $3.3 \mathrm{~m}^{2} /$ ha. It varies from $4.1 \mathrm{~m}^{2} / \mathrm{ha}$ in the municipality of Tenghory to $1.8 \mathrm{~m}^{2} /$ ha in that of Niamone, and $2.8 \mathrm{~m}^{2} /$ ha and $2.2 \mathrm{~m}^{2} /$ ha in the municipalities of Coubalan and Ouonck respectively (Table 3). The species with the largest land areas at the district level are Adansonia digitata $\left(0.41 \mathrm{~m}^{2} / \mathrm{ha}\right)$,
Faidherbia albida $\left(0.31 \mathrm{~m}^{2} / \mathrm{ha}\right)$, Cola cordifolia $\left(0.25 \mathrm{~m}^{2} / \mathrm{ha}\right)$ and Parkia biglobosa $\left(0.25 \mathrm{~m}^{2} / \mathrm{ha}\right)$.

In the Tenghory district, the density observed is 21.8 plants/ha. It is higher in the municipality of Coubalan (29.6 individuals/ha) than in the municipalities of Tenghory (22.9 individuals/ha), Ouonck (16.9 individuals/ha) and Niamone (12.6 ft/ha) (Table 4). The species with the highest densities in the parks are: Pterocarpus erinaceus (2.9 individuals/ha), Elaeis guineensis (2.5 individuals/ha), Faidherbia albida (2.3 individuals/ha), Anacardium occidentale (2.0 individuals/ha) and Parkia biglobosa (1.7 individuals/ha).

The agroforestry parks in Tenghory District are very diversified with Shannon Weaver $\left(\mathrm{H}^{\prime}\right)$ and Pielou $(\mathrm{E})$ indices of 3.8 bits and 0.64 bits respectively (Table 4). At the municipal level, this diversity is higher in Coubalan $\left(\mathrm{H}^{\prime}=4\right.$; $\mathrm{E}=0.79)$ and lower in Ouonck $\left(\mathrm{H}^{\prime}=2.2 ; \mathrm{E}=0.50\right)$.

Table 4. Structural parameters of woody vegetation in agroforestry parks according to municipalities and Tenghory district.

\begin{tabular}{|c|c|c|c|c|c|c|}
\hline \multirow{2}{*}{ Ecological parameters } & \multirow{2}{*}{\multicolumn{2}{|c|}{ Tenghory district }} & \multicolumn{4}{|c|}{ Communes } \\
\hline & & & Tenghory & Ouonck & Coubalan & Niamone \\
\hline Canopy cover (\%) & & 13,7 & 15,9 & 15,3 & 11,7 & 6,4 \\
\hline Density (indiduals/ha) & & 21,8 & 22,9 & 16,9 & 29,6 & 12,6 \\
\hline \multirow{2}{*}{$\begin{array}{l}\text { Shannon Diversity Index } \\
\text { Pielou regularity Index }\end{array}$} & $H^{\prime}$ & 3,8 & 3,7 & 2,2 & 4,0 & 3,2 \\
\hline & $\mathrm{E}$ & 0,64 & 0,64 & 0,50 & 0,79 & 0,63 \\
\hline
\end{tabular}

Legend: $H^{\prime}=$ Shannon Weaver Index E= Pielou Index.

\subsection{Characteristics of the Agroforestry Parks in the Tenghory District}

Table 5 presents the distribution of variances from the Principal Component Analysis (PCA) of the characteristics of the parks in Tenghory district according to the municipalities. The first axis (F1) accounts for $51 \%$ of the variance and the second axis (F2) accounts for $31.6 \%$. The first two axes thus account for $82.6 \%$ of the total variance. The factorial design $\mathrm{F} 1 \mathrm{xF} 2$ thus allowed a good representation of the information contained in the matrix.

Table 5. Distribution of eigenvalues or variances along PCA factor axes.

\begin{tabular}{llll}
\hline & F1 & F2 & F3 \\
\hline Eigenvalues & 3.570 & 2.215 & 1.215 \\
Inertia (\%) & 51,000 & 31.638 & 17.362 \\
Cumulated inertia (\%) & 51,000 & 82.638 & 100.000 \\
\hline
\end{tabular}

On the basis of the floristic and structural characteristics of the agroforestry parks in the Tenghory district, Principal Component Analysis (PCA) made it possible to discriminate between different groups of agroforestry parks (Figure 3). Thus, along the F1 axis, two large groups of agroforestry parks can be distinguished:

1) Group A, located on the positive $x$-axis, which is divided into two subgroups (A1 and A2) along the yaxis. Sub-group A1, located on the positive y-axis, is characteristic of the agroforestry parks in the municipality of Tenghory with a high coverage rate (CT), specific richness (S) and basal area (ST). Subgroup A2, representing the agroforestry parks of the municipality of Coubalan, is characterized by a high density (DENS) and specific diversity (ShannonWeaver index $\left(\mathrm{H}^{\prime}\right)$ and Pielou equitability index (E)) but with a low regeneration rate (TR).

2) Group B, located on the negative $x$-axis side, contrasts with Group A. It contains sub-groups B1 and B2. Sub-group B1, representing the parks of the commune of Ouonck, is characterized by a low density (DENS), and a low specific diversity ( $\mathrm{H}^{\prime}$ and E) but with a high regeneration rate (TR). Sub-group $\mathrm{B} 2$, representing the parks of the municipality of Niamone, is characterized by a low coverage rate 
(TC), a low specific richness (S) and a low basal area (ST). It thus appears that the $\mathrm{x}$-axis, which has made it possible to distinguish between the parks in group A characterised by high specific diversity, and the parks in group B characterised by low diversity, corresponds to a diversity gradient.

\subsection{Structure of Woody Vegetation in Parks (Trees of D1.3 $\geq 5 \mathrm{~cm}$ )}

\subsubsection{Vertical Structure}

It appears from figure 4 that individuals of height greater than or equal to $10 \mathrm{~m}$ are the most represented in the 4 communes and at the district level. The proportion of woody individuals greater than $10 \mathrm{~m}$ in height is $71.2 \%, 54.5 \%$, $48.8 \%$ and $43.6 \%$ respectively in the municipalities of Ouonck, Niamone, Tenghory and Coubalan. At the level of the district this proportion is $50.5 \%$.

At the level of the district, the height class [2-4] groups the least number of individuals with $9.1 \%$ of woody individuals.

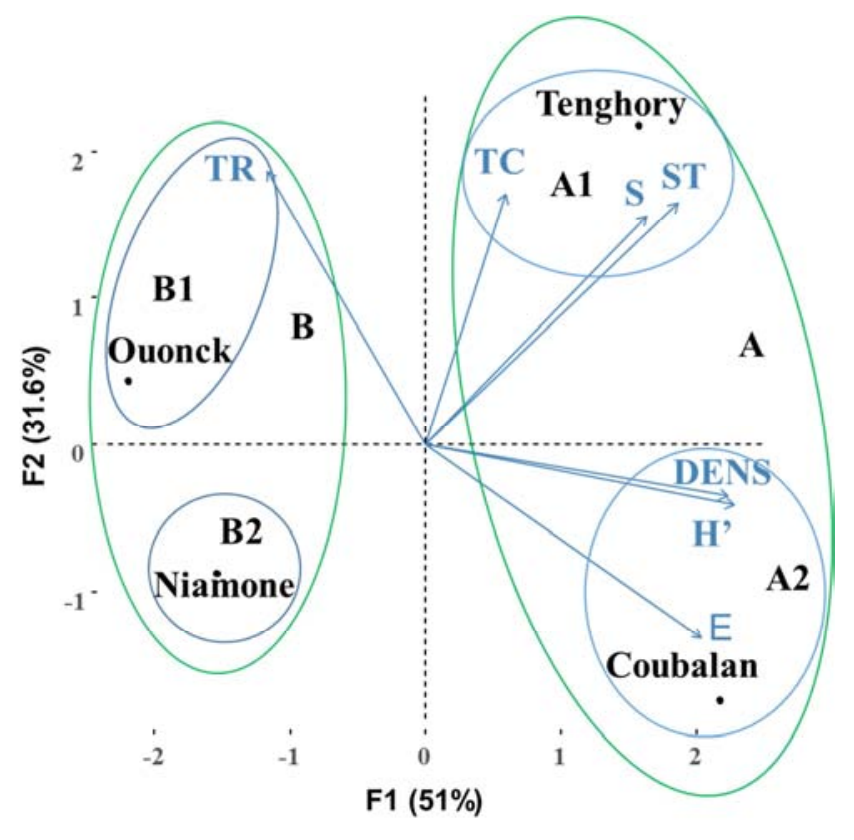

Figure 3. Characteristics of agroforestry parks in the Tenghory district.

Legend: DENS (Density), TC (coverage rate), ST (basal area), H (shannon wearver index), E (Pielou index), S (Specific richness), TR (Regeneration rate).

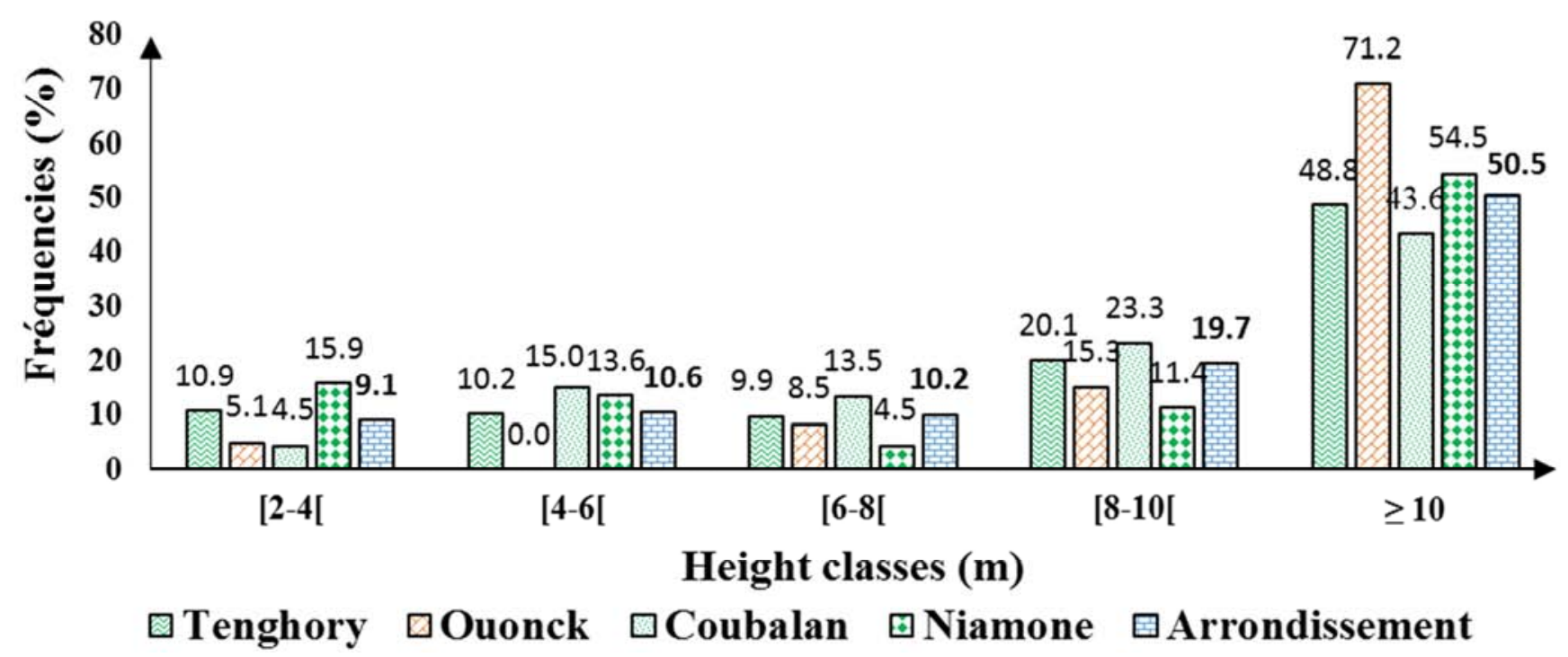

Figure 4. Distribution in height classes of woody stand individuals (trees of D1.3 $\geq 5 \mathrm{~cm}$ ) in agroforestry parks according to communes and the Tenghory district.

\subsubsection{Horizontal Structure}

In the agroforestry parks of the Tenghory district, the diameter class [5-25] is the best represented with $45.8 \%$ of the individuals. This diameter class is also more represented in the municipalities of Coubalan and Tenghory with $72.2 \%$ and $41.3 \%$ of the individuals in the woody stand of the parks, respectively. In the municipalities of Niamone and Ouonck it is the class of diameter between 25 and $45 \mathrm{~cm}$ that is the most represented with respectively 54.5 and $45.8 \%$ of the individuals in the woody stand of the parks. Globally, the horizontal structure of the woody vegetation in the parks is characterized by a predominance of individuals with a diameter $<45 \mathrm{~cm}$. At the district level, these individuals represent $80.5 \%$ of the woody stand in the parks. According to the municipalities, individuals with diameter $<45 \mathrm{~cm}$ constitute $89.5,79.9,78.6$ and $71.2 \%$ of the woody population of the agroforestry parks in the municipalities of Coubalan, Niamone, Tenghory and Ouonck respectively. Overall, it appears that for the municipalities of Niamone and Ouonck, the structure by diameter classes of the individuals in the woody stand presents a normal distribution with a predominance of individuals of 
intermediate classes. In the municipalities of Tenghory, Coubalan and in the district, the structure is L-shaped with a predominance of young individuals, with a diameter between 5 and $25 \mathrm{~cm}$ and a low representation of largediameter individuals (Figure 5).

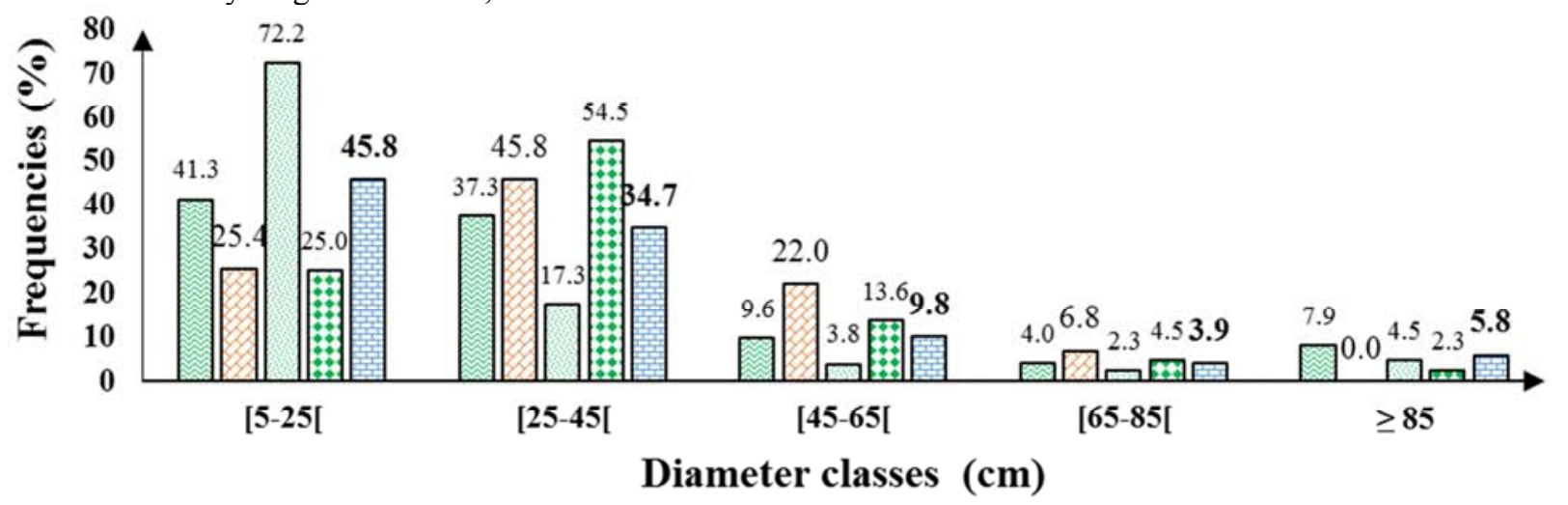

$\square$ Tenghory $\square$ Ouonck $\square$ Coubalan $\square$ Niamone $\square$ Arrondissement

Figure 5. Distribution by diameter classes of individuals in the woody stand of agroforestry parks according to municipality and district.

\section{Discussion}

The purpose of this work is to contribute to a better knowledge of the state of the agroforestry parks in the Tenghory district. The study revealed the presence of 64 woody species divided into 53 genera and 20 botanical families in the agroforestry parks of the Tenghory district. The predominant families were Fabaceae (29.7\%), Combretaceae (12.5\%) and Moraceae (7.8\%). Of the 64 species inventoried, the municipalities of Tenghory, Coubalan, Niamone and Ouonck recorded 57; 33; 32 and 22 species respectively. These parks are quite diversified with a Shannon index of 3.8 bits in the district. This index varies from 4 bits in Coubalan to 2.2 bits in Ouonck. These results are close to those of [20] who obtained in the traditional agroforestry parks in Elaeis guineensis in Lower Casamance a specific richness of 69 woody species divided into 58 genera, belonging to 23 botanical families. Moreover, they observed a predominance of Fabaceae (20\%) and Moraceae (16.18\%), which confirms our results. In addition, for species diversity, the authors observed Shannon indices of 4.12 bits at Kaguite; 3.27 bits at Carounate and 2.93 bits at Kabiline. The floristic richness obtained in the parks of the Tenghory district is less important than that of Elaeis guineensis parks in Guinea Bissau in the Cacheu region where 75 species distributed in 63 genera and 25 botanical families were recorded [21].

The high frequency of presence of Icacina senegalensis (74.7\%) and Guiera senegalensis (64.6\%) species in the district reflects the high regeneration capacity of the latter after clearing. These results corroborate those of [22] who cited Icacina senegalensis (40.3\%) and Guiera senegalensis $(59.7 \%)$ as the most frequent species in the fields and fallows of the southwestern groundnut basin in Senegal. The inverse correlation observed between regeneration rate and species diversity could be explained by the predominance of a few species such as Icacina senegalensis and Guiera senegalensis in the woody stand. This is due to their high regeneration capacity. The relatively low values of cover rate $(13.7 \%)$, basal area $(3.3$ $\left.\mathrm{m}^{2} / \mathrm{ha}\right)$ and density (21.8 feet/ha) in the parks of the Tenghory district reflect the impact of human intervention on woody trees in the parks. Indeed, farmers tend to reduce the total number of plants and species while favouring a few preferred species [23]. Also, it is difficult to cultivate with a certain density of trees in the fields [8].

Overall, the woody stand in the agroforestry parks of the Tenghory district presents a vertical structure with a predominance of large individuals $(\geq 10 \mathrm{~m})$ and a horizontal "L" structure indicating a predominance of small diameter individuals (between 5 and $25 \mathrm{~cm}$ ). As a result, agroforestry parks are characterized by a predominance of individuals with small trunk diameter but relatively large size $(\geq 10 \mathrm{~m})$. These results are in contrast to those [24] who found a predominance of large-diameter individuals (diameter $\geq 50$ $\mathrm{cm}$ ) in the anthropogenic savannahs of Parkia biglobosa and Piliostigma reticulatum in Burkina Faso.

\section{Conclusion and Perspectives}

At the end of this study, the characteristics of the woody flora and vegetation of the agroforestry parks in the Tenghory district were established. These parks present a specific richness of 64 woody species divided into 53 genera and 20 botanical families. The most represented families are those of Fabaceae and Combretaceae with respectively $29.7 \%$ and $12.5 \%$ of the individuals inventoried. Icacina senegalensis $(74.7 \%)$ and Guiera senegalensis $(64.6 \%)$ are the most frequent species in these parks. The density of trees is 21.8 trees/ha, and the basal area and cover rate are $3.3 \mathrm{~m}^{2} / \mathrm{ha}$ and $13.7 \%$ respectively. It would be important: to continue this study in the other departments of Lower Casamance (Ziguinchor and Oussouye) in order to lay the foundations 
for a more rational management of these important ecosystems; and finally to raise awareness among farmers in order to prepare them for a more rational management of agroforestry parks.

\section{References}

[1] Boffa, J. M., (2000). Agroforestry parks in West Africa: keys to conservation and sustainable management. Unasylva 200 51: 11-17.

[2] Smektala, G., Peltier, R., Sibelet, N., Leroy, M., Manlay, R., Njiti, C. F., Ntoupka, M., Njiemoun, A., Palo, O. and Tapsou., 2005. Sahelian agroforestry parks: from Conservation to Management. VertigO 6 (2): 1-13.

[3] Badiane, M., Camara, B., Ngom, D. and Diedhiou, M. A. A. 2019. Community perception of traditional agroforestry parks in Faidherbia albida (Del.) Chev. In Lower Casamance, Senegal. Africa SCIENCE 15 (1): 214-226.

[4] Camara, B., Sagna, B., Ngom, D., Niokane, M. and Gomis, Z. D. (2017). Socio-economic importance of Elaeis guineensis Jacq. (Oil palm) in Lower Casamance (SENEGAL). European Scientific Journal April 2017 edition Vol. 13, No. 12 ISSN: 1857-7881 (Print) e-ISSN 1857-7431.

[5] Sambou, A., Camara, B., Goudiaby, A. O. K., Coly, A. and Badji, A. (2018). Perception of local populations on the ecosystem services of the classified and managed forest of Kalounayes (Senegal). Revue Francophone du Développement Durable, special issue $n^{\circ} 6:$ 69-86.

[6] Gutierrez, M. L. (2000). Production and marketing of the afitin Fon in the Abomey-Bohicon region of Benin. CERNA, CNEARC, CIRAD, $124 \mathrm{p}$.

[7] Mahamane, A. (1997). Structure, functioning and dynamics of agroforestry parks in western Niger. $\mathrm{PhD}$ thesis in applied biological sciences, option: plant biology and ecology. University of Ouagadougou, Ouagadougou, 214 p.

[8] Thiombiano, D. N. E., Lamien, N., Dibong, S. D. and Boussim. (2010). Status of stands of woody species in the rural communes of Pobé-Mengao and Nobéré (Burkina Faso). Journal of Animal \& Plant Sciences 9 (1): 1104-1116.

[9] Ky, J. M. K. (2010). The state of plant resources providing non-timber forest products in the Bissiga Forest, Centre-East Burkina Faso. PhD thesis in applied biological sciences. University of Ouagadougou, Ouagadougou, 140 p.

[10] Sene, A. (1994). Socio-economic study of park systems in the groundnut basin: case of sterculia setigera and cordyla pinnata. Confirmatory thesis at ISRA, Senegal, $86 \mathrm{p}$.

[11] Diedhiou, M. A. A., Faye, E., Ngom, D. and Toure, M. A. (2014). Identification and floristic characterization of agroforestry parks in the island terroir of Mar Fafaco (Fatick, Senegal). Journal of Applied Biosciences 79: 6855-6866.
[12] Sagna, P. (2005). Climate dynamics and its recent evolution in the western part of West Africa. PhD thesis. Cheikh Anta Diop University of Dakar. 786 p.

[13] Charreau, C. and Fauck, R. (1967). Soils in Senegal. Senegalese Studies 9: 115-54.

[14] Goudiaby, M. (2013). Agroforestry parks in Lower Casamance: contribution of Parkia biglobosa (néré) to poverty risk reduction of households in the rural community of Mangangoulack, Senegal. Master's thesis in agroforestry. Laval University, Quebec Canada. 118 p.

[15] Ouédraogo, A., Adjima, T., Karen, H.-H. and Sita, G. (2006). Juvenile stand structure and potential for regeneration of woody trees in eastern Burkina Faso. Studies Flor. Veg Burkina Faso 10: 17-24.

[16] Gning, O. (2008). Characteristics of fodder woody plants in the Khossanto community rangelands (Kédougou, Eastern Senegal). DEA thesis in Plant Biology, UCAD, 78p.

[17] Ramade, F. (2003). Elements of Ecology: Fundamental ecology. 3rd edition, Dunod, Paris; 690p.

[18] Frontier, S. and Pichod-Viale, D. (1995). Ecosystems: structure, functioning, evolution. Masson, $447 \mathrm{p}$.

[19] Devineau, J. L., Leordier, C. and Vattoux R. (1984). Evolution of the specific diversity of the woody population in a preforest succession of colonization of a savannah protected from fires (Lamto, Côte d'Ivoire). Conservatoire et jardin botanique de Genève, 39 (1): 103-133 p.

[20] Ngom, D., Camara, B., Gomis, Z. D. and Sagna, B. (2018). Floristic procession, structural parameters and anthropisation indicators of agroforestry parks in Elaeis guineensis Jacq. in Lower Casamance, Senegal. Journal of animal and plant sciences. 36 (3): 5919-5932.

[21] Sagna, B., Ngom, D., Camara, B., Sambou, A., Diedhiou, M. A. A., Goudiaby, M., Mane, A. S. and Le coq, Y. (2019). Ecological Characterization of Elaeis guineensis Jacq. Agroforestry Parklands in the Cacheu Region (Guinea Bissau). American Journal of Agriculture and Forestry. Vol. 7, No. 6, 2019, pp. 321-329.

[22] Mbow, M. A., Faye, E. H., Kaire M., Akpo, LE. and Diouf, M. (2005). Diversity of Sudanian woody vegetation in SOUTH-WESTern land use systems in the groundnut basin (Senegal). Journal of Science and Technology pp. 21-34.

[23] Boffa, J.-M. (1995). Productivity and management of agroforestry parklands in the Sudan zone of Burkina Faso, West Africa. Ph. D. Dissertation. Purdue University, West Lafayette, Indiana, USA. 101p.

[24] Ouedraogo, O., Thiombiano, A., Hahn-Hadjali K. \& Guinko S. (2008). Diversity and structure of woody groups in the Arly National Park (eastern Burkina Faso). Flora and Vegetatio Sudano-Sambesica, 11: 5-16. 